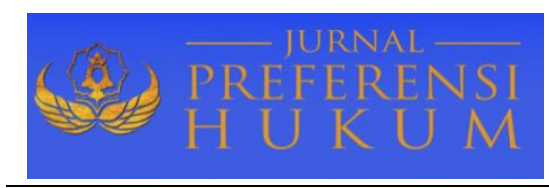

Jurnal Preferensi Hukum | ISSN: XXXX | E-ISSN: XXXX

Vol. 1, No. 2 - September 2020, Hal. 154-158| Available Online

at https://www.ejournal.warmadewa.ac.id/index.php/juprehum

DOI: http://doi.org/ 10.22225/jph.v1i2.2353.154-158

\title{
JAKSA SELAKU EKSEKUTOR DALAM PUTUSAN PENGADILAN TINDAK PIDANA PEMBUNUHAN
}

\author{
I Wayan Edi Kurniawan, Anak Agung Sagung Laksmi Dewi, I Made Minggu Widyantara \\ Fakultas Hukum Universitas Warmadewa, Denpasar-Bali, Indonesia
}

\begin{abstract}
Abstrak
Penegakan dari sistem peradilan pidana di Indoensia dapat juga dilakukan dengan melaksankan putusan pengadilan yang telah berkekuatan hukum tetap. Pihak yang memiliki kewenangan melaksanakan putusan hakim tersebut adalah Jaksa. Dalam isi putusan pidana kejaksaan mempunyai kewenangan untuk segera melakukan eksekusinya sesuai Kitab Undang-undang Hukum Acara Pidana. Penelitian ini bertujuan untuk mengetahui kewenangan jaksa dalam melaksanakan eksekusi, dan untuk mengetahui mekanisme eksekusi tindak pidana pembunuhan. Penelitian ini menggunakan metode normatif, pendekatan secara perundang-undangan, pendekatan konseptual, bahan hukum primer, bahan hukum sekunder, bahan hukum tersier, studi dokumen, studi kepustakaan, studi internet serta analisis interpretasi hukum, dan analisis deskriptif. Satu-satunya lembaga eksekutor di Negara Indonesia adalah Kejaksaan Republik Indonesia. Arti dari eksekutor yaitu pihak yang memiliki kewenangan untuk melaksankan putusan pengadilan dengan berdasarkan kepada undang-undang yang berlaku. Hasil penelitian menunjukkan bahwa dalam menjalankan putusan pengadilan kejaksaan mempunyai tugas dan fungsinya salah satunya sebagai pelaksana selain juga sebagai penuntut umumnya. Suatu putusan yang dapat dijalankan eksekusinya hanyalah yang sudah berkekuatan hukum tetap dan tidak ada upaya hukum lagi. Jaksa sebagai aparat penegak hukum dalam melaksanakan tugasnya harus berdasarkan pada aturan hukum yang berlaku. Jangan sampai jaksa melanggar aturan yang bukan menjadi kewenangannya. Aparat penegak hukum yang melakukan eksekusi haruslah menjalankan dengan secepatnya eksekusi tersebut dan tidak ada pelaku tindak pidana yang terlambat di eksekusi.
\end{abstract}

Kata Kunci: Eksekutor, Jaksa, Tindak Pidana Pembunuhan.

\begin{abstract}
Enforcement of the criminal justice system in Indonesia can also be carried out by implementing court decisions that have permanent legal force. The party that has the authority to implement the judge's decision is the prosecutor. In the contents of the criminal decision, the prosecutor's office has the authority to immediately carry out the execution in accordance with the Criminal Procedure Code. This study aims to determine the authority of the prosecutor in carrying out the execution, and to determine the execution mechanism for the crime of murder. This research uses normative methods, statutory approaches, conceptual approaches, primary legal materials, secondary legal materials, tertiary legal materials, document studies, literature studies, internet studies and analysis of legal interpretations, and descriptive analysis. The only executing agency in the State of Indonesia is the Attorney General's Office of the Republic of Indonesia. The meaning of executor is the party who has the authority to carry out court decisions based on the applicable law. The results showed that in carrying out court decisions, the prosecutor's office had duties and functions, one of which was as an executor as well as a general prosecutor. A decision that can be executed is only one that has permanent legal force and there are no more legal remedies. Prosecutors as law enforcement officers in carrying out their duties must be based on the applicable legal rules. Do not let the prosecutor violate rules that are not under their authority. Law enforcement officials who carry out executions must carry out the execution as quickly as possible and no criminal offender is executed late.
\end{abstract}

Keywords: Executor, Prosecutor, Murder crime.

\section{PENDAHULUAN}

Para hakim pengadilan selesai memutus suatu perkara bukan berarti setelah itu perkara selesai, ada kalanya para pihak yang berperkara di pengadilan merasa tidak puas dan mengajukan hukum atas suatu putusan hakim. Keadilan haruslah dapat dirasakan oleh semua pihak yang terlibat dalam perkara termasuk tindak pidana baik dari terpidana. Tujuan akhir dari Kitab Undang-undang Hukm Acara Pidana yang harus diperhatikan dapat terciptanya keadilan pada proses dilakukannya eksekusi (Muhammad, 2007). Dalam hal putusan hakim yang sudah dibacakan diterima oleh para pihak yang berperkara dan tidak dimintakan upaya hukum oleh para pihak ataupun memang tidak dapat dimintakan upaya hukum lagi, maka putusan hakim tersebut dinyatakan berkekuatan hukum tetap (in kracht) (Hamang, 2003). Putusan hakim yang telah berkekuatan hukum tetap tersebut kemudian akan dilaksanakan oleh pihak 
yang berwenang atau biasa dikenal dengan istilah eksekusi. Kewenangan melaksanakan putusan hakim tersebut adalah Jaksa. Kejaksaan mempunyai kewenangan dalam melakukan putusan hakim haruslah perkara yang sudah diputus mempunyai kekuatan hukum tetap dan tidak ada lagi upaya hukum bagi terpidana yang dalam putusannya berisi amar putusan yang memuat suatu pidana. Tugas dari pelaksana putusan hakim ataupun pengadilan ditugaskan kepada jaksa sesuai dengan yang diatur dalam pasal 1 butir 1 Undang-undang nomor 14 tahun 2004 tentang Kejaksaan Republik Indonesia. Penegakan hukum di Indonesia juga bagian dari melaksankan suatu putusan pengadilan yang berkekuatan hukum tetap yang dilakukan oleh para pelaksana penegak hukum pidana.

Pada umumnya perlu diketahui juga lembaga maupun aparat pelaksana putusan pengadilan yang mempunyai kekuatan hukum tetap adalah Institusi Kejaksaan Republik Indonesia. Hal ini diatur juga pada pasal 270 Undang-undang nomor 8 tahun 1981 tentang Kitab Undang-undang Hukum Acara Pidana bagaimana dalam melaksanakan eksekusi yang mempunyai kekuatan hukum tetap yang dilaksanakan oleh jaksa serta panitera juga memberikan salinan putusan pengadilannya. Lebih lanjutnya hal ini juga diatur dalam pasal 54 ayat 1 Undang-undang nomor 48 tahun 2009 tetang Kekuasaan Kehakiman yang memberikan penjelasan mengenai jaksa sebagai pihak pelaksana suatu putusan hakim tindak pidana. Kitab Undang-Undang Hukum Acara Pidana dalam proses eksekusi diatur pada Bab XIX tentang bagaimana dalam pelaksanaan suatu putusan hakim atau pengadilan yang ada pada pasal 207 pasal 276. Selanjutnya tempo waktu dari pelaksanaan putusan diperjelas pada pasal 197 ayat 3 Kitab Undang-undang Hukum Acara Pidana yang menjelaskan mengenai putusan harus dijalankan segera menurut aturan dalam undang-undang ini (KUHAP). Pada ketentuan Kitab Undangundang Hukum Acara Pidana pada pasal 270 dinyatakan bahwa putusan pengadilan dilakukan saat mempunyai kekuatan hukum tetap dan jaksa menerima salinan putusan itu dari panitera pengadilan.

Apabila dari pasal 270 Kitab Undang-undang Hukum Acara Pidana ini di hubungkan dengan pasal 197 ayat 3 Kitab Undang-undang Hukum Acara Pidana maka arti dari kata segera dapat ditafsirkan segera setelah jaksa menerima salinan putusan eksekusi dari panitera pengadilan. Aturan ini sesuai dengan apa isi dari surat edaran jaksa agung mengenai tanggung jawab dan tugas jaksa sebagai eksekutor putusan hakim pengadilan. Karena hal terkait eksekusi ini sudah sangat jelas dan terang diatur di dalam KUHAP, sehingga tidak lagi dibutuhkan tafsir apalagi aturan operasional yang lebih rendah untuk menerangkannya. Apalagi kalau kemudian aturan tersebut menimbulkan kerancuan dan pertentangan hukum. Kalau kewenangan yang diperoleh dengan undang-undang dilemahkan normanya dengan peraturan pemerintah (apalagi Surat Edaran) yang kelasnya jauh lebih rendah dari UndangUndang, itu berarti inkonstitusional.

Atas dasar aturan inilah eksekusi harus dengan salinan putusan bukan hanya dengan petikan putusan saja yang sering ditemui dalam prakteknya hanya dengan petikan putusan saja digunakan oleh jaksa. Tindakan yang dilakukan sungguh bertentangan dengan apa yang diatur pada undang-undang dan surat yang sudah diedarkan oleh Jaksa Agung Republik Indonesia. Keduanya pastilah berbeda antara petikan putusan dan salinan putusan pada isinya. Petikan suatu putusan dalam pidana hanya berisi tentang amar dari putusan tanpa menjelaskan lebih legkap mengenai apa landasan pertimbangan hakim dalam memutus suatu perkara. Sedangkan dari salinan suatu putusan pengadilan adalah merinci lebih lengkap dan merupakan turunan dari putusan yang memuat seluruh aturan seperti pada pasal 197 ayat 1 Kitab Undang-undang Hukum Acara Pidana. Suatu putusan pengadilan resmi saja seandainya tidak memuat dan terpenuhinya salah satunya dari 12 ketentuan pada pasal 197 ayat 1 Kitab Undang-undang Hukum Acara Pidana hal ini dapat dikatakan batal demi hukum. Apalagi petikan putusan pengadilan jelas-jelas hanya berisi extract (sari ataupun kutipan) daripada putusan pengadilan dan berisi hanya beberapa ketentuan pada pasal 197 ayat 1 Kitab Undang-undang Hukum Acara Pidana.

Berdasarkan uraian latar belakang di atas, maka maka penelitian ini bertujuan untuk mengetahui kewenangan jaksa dalam melaksankan eksekusi, dan untuk mengetahui mekanisme eksekusi tindak pidana pembunuhan.

\section{METODE PENELITIAN}

Penelitian ini menggunakan metode penelitian hukum normatif. Tipe pendekatan masalah dalam penulisan ini yaitu pendekatan perundang-undangan (statute approach) serta pendekatan konseptual (conceptual approach). Adapun sumber bahan penelitian hukum yang dipergunakan yakni bersumber dari penelitian kepustakaan ( library research) yaitu: Bahan Hukum Primer yang merupakan bahan yang dipakai berupa peraturan Perundang-Undangan yakni, Undang-undang Negara Republik Indonesia Tahun 1945, Kitab Undang-undang Hukum Acara Pidana, Kitab Undang-undang Hukum Pidana, 
Undang-undang Nomor 48 Tahun 2009 Tentang Kekuasaan Kehakiman dan Undang-undang Nomor 16 Tahun 2004 Tentang Kejaksaan. Seterusnya, bahan Hukum Sekunder adalah bahan yang diproleh atas suatu kajian kepustakaan (Library Reseach) yakni, dengan mebaca bukum hukum terkait penelitian surat kabar serta sumber dari internet yang berhubungan pada penulisan hukum jaksa selaku eksekutor dalam putusan pengadilan tindak pidana pembunuhan. Bahan hokum berikutnya, Bahan Hukum Tersier yaitu bahan-bahan hukum yang diperoleh dari bahan berupa kamus hukum, kamus besar bahasa Indonesia, ensiklopedia, dan yang lain yang berkaitan dengan penelitian ini. Teknik yang dipakai dalam pengumpulan bahan hukum penulisan ini adalah sebagai berikut: Studi Dokumen merupakan yang bersumber dari bahan hukum Negara seperti peraturan Perundang-undangan yang berkaitan dengan penulisan hukum yang dilakukan penulis; Studi Kepustakaan merupakan pengumpulan data dengan melakukan studi penelaahan terhadap buku-buku dan catatan yang berkaitan dengan masalah yang hendak dipecahkan; Studi Internet merupakan mengumpulkan bahan dengan melakukan pencarian kata inti masalah yang hendak diteliti melalui internet untuk memecahkan masalah.

Metode yang digunakan dalam pengolahan maupun dalam analisis bahan hukum yang digunakan dalam penelitian ini adalah analisis interpretasi hukum, yaitu penafsiran hukum yang dilakukan terhadap apakah bisa jaksa melakukan eksekusi hanya dengan kutipan putusan. Analisis deskriptif merupakan hasil dari penelitian hukum bertujuan agar diperoleh suatu hasil gambaran menyeluruh, tetapi tetap berada pada sistematik terutama dalam hal fakta yang berkaitan dengan masalah yang akan diteliti dalam penulisan hukum yang diambil penulis.

\section{HASIL DAN PEMBAHASAN}

\section{Kewenangan Jaksa Dalam Melakukan Eksekusi Berdasarkan Pasal 270 KUHAP}

Kewenangan dasar kata dari "wenang" yang berarti sebagai hak, kekuaasaan, dan berwenang yang dimiliki untuk dalam melakukan sesuatu tindakan (Bahasa, 1990). Kewenangan adalah apa yang disebut sebagai kekuasaan formal yang muncul dari kekuasaan Eksekutif, kekuasaan Legislatif ataupun kekuasaan Yudikatif yang diberikan oleh undang- undang. Dari suatu Undang-undang, kekuasaan formal dari kewenangan itu berasal, sedangkan wewenang sendiri merupakan spesifikasi suatu kewangan yang berarti apabila organ atau lembaga Negara diberikan suatu kewenangan maka ia harus menjalankan kewenangan yang dimilikinya. Dalam halnya organ suatu Negara memiliki kewenangannya dapat menjalankan tindakan nyatanya iyaitu membuat aturan ataupun memberikan suatu putusan yang didasari pada kewenangannya yang didapat dalam konstitusi baik secara mandate, atribusi maupun pendelegasian.

Eksekusi pada putusan pengadilan merupakan hal yang perlu dilakukan sebagai pemenuhan tuntutan dari Jaksa Penuntut Umum kepada Terdakwa, tetapi tidak semua putusan pengadilan dapat langsung dilakukannya eksekusi oleh jaksa. Adapun eksekusi putusan pengadilan yang belum dapat dilakukan oleh jaksa yaitu putusan yang belum mempunyai hukum tetap dan masih adanya upaya hukum untuk terdakwa melakukannya. Putusan yang hanya dapat dilakukannya eksekusi hanyalah putusan yang mempunyai hukum tetap saja karena di dalam putusan tersebut sudah adanya ikatan hukum antara pihak yang terjerat perkara hukum (Sutarto, 2008). Hukuman eksekusi yang di berikan kepada terpidana di jalankan oleh jaksa sesusai dengan apa isi dalam amar putusannya.

Dalam melakukan penuntutan persidangan, kejaksaan memperkuat lagi peran serta kedudukannya melalui Undang-undang Kejaksaan sebagai lembaga pada pemerintahan yang menjalankan kekuasaan dari Negara. Aturan ini bertujuan pada saat pelaksanaan tugas, wewenang serta fungsinya terlepas adanya pengaruh dari suatu kekuasaan lain adalah untuk melindungi profesi jaksa dalam melakukan tugas dan fungsinya. Jaksa saat melaksanakan tugas serta fungsinya haruslah juga taat terhadap wewenang, fungsi serta tugasnya sesuai yang diatur oleh Undang-undang Kejaksaan Republik Indonesia. Bagi jaksa tugas merupakan amanat yang wajib dilaksanakan pada suatu jabatan institusi. Sedangkan wewenang merupakan hal yang berkaitan dengan pelaksanaan tugas kompetensi yuridiksi , baik dari kompetensi mutlak itu sendiri ataupun kompetensi relatif (Effendy, 2007).

\section{Prosedur Eksekusi Tindak Pidana Pembunuhan}

Pengertian tindak pidana yang dimuat pada Kitab Undang-undang Hukum Pidana sering disebut juga oleh pembuat suatu Undang-undang strafbaarfeit. Dari para pembentuk Undang-undang juga tidak memberikan penjelasan strafbaarfeit itu lebih rinci. Para pakar dari hukum pidana sering memakai istilah lain dengan delik, tindak pidana, peristiwa pidana dan perbuatan pidana. Kata "Strafbaar Feit" adalah Bahasa Belanda yang terdiri dari tiga kata, yaitu "Straf" merupakan hukuman atau pidana, "baar" yang merupakan dapat atau boleh serta "Feit" yang merupakan peristiwa, tindak, perbuatan 
dan pelanggaran. Jadi istilah kata Strafbaarfeit merupakan suatu perbuatan yang dapat dipidanakan ataupun peristiwa yang dapat dipidanakan (I Made Widnyana, 2010, hlm 32). Sehingga suatu tindak pidana merupakan perilaku yang dilakukan tidak hanya dirumuskan pada undang-undang tentang pidana atau kejahatan tetapi dapat dilihat dari pandangan tentang devisi ( penyelewangan dari peraturan Undang-undang Dasar Negara Republik Indonesia Tahun 1945 ), kejahatan serta dari kualitas kejahatan yang dilakukan berubah-ubah (Gosita, 1983).

Mereka pakar hukum tidak menjelaskan definisi ataupun pengertian mengenai apakah arti dari pembunuhan, tetapi masih banyak pakar yang menggolongkan pembunuhan itu pada suatu kejahatan terhadap nyawa ataupun jiwa orang lain. Tindakan penyerangan terhadap nyawa dari orang lain merupakan suatu kejahatan terhadap nyawa atau dalam bahasa latin misdrijven tegen bet leven. Perbuatan yang menghilangkan nyawa dari orang lain secara sengaja dan niat merupakan suatu perbuatan tindak pembunuhan. Dalam buku II Bab XIX ( pasal 338 sampai dengan pada pasal 350 ) Kitab Undang-undang Hukum Pidana diatur mengenai apa itu nyawa. Sehingga nyawa merupakan sesuatu yang berkaitan dengan tindak pidana kehidupan seseorang dalam melangsungkan kehidupannya.

Setelah selesai pada semua proses persidangan, hakim lalu mengambil suatu putusan yang telah dirapatkan sebelumnya oleh para hakim anggota lain dan disampaikan oleh hakim ketua. Keputusan dari hakim haruslah diucapkan pada sidang yang dibuka dan terbuka untuk umum, agar memiliki kekuatan di dalam hasil putusan tersebut. Putusan itu haruslah dijalankan selanjutnya oleh lembaga eksekutor dan tidak mungkin hakim yang menjalankan sendiri yaitu yang menjadi eksekutor adalah jaksa. Jaksa melakukan eksekusi harus berdasarkan pada pidana yang dimuat dalam putusan yang diberikan salinan putusan oleh panitera dan menjalankan sesuai dengan aturan eksekusi.

\section{SIMPULAN DAN SARAN}

\section{Simpulan}

Berdasarkan uraian di atas maka disimpulkan bahwa lembaga yang mempunyai wewenang dalam melakukan eksekusi di Negara satu-satunya adalah Kejaksaan Republik Indonesia. Arti dari eksekutor merupakan suatu pihak yang dapat menjalankan hasil putusan pengadilan yang telah berkekuatan humum tetap serta sesuai dengan undang-undang yang mengatur proses eksekusi. Jaksa merupakan suatu pejabat yang diberikan oleh undang-undang untuk menjalankan putusan hakim ataupun pengadilan dan wewenang yang lainnya berdasarkan ketentuan dalam undang-undang. Adapun kewenangannya serta tugasnya dari seorang jaksa dalam pidana diatur pada pasal 30 ayat 1 Undang-undang tentang Kejaksaan iyaitu, menjalankan pengawasan terhadap pelaksanaan putusan pidana bersyarat, putusan pidana pengawasan, dan keputusan lepas bersyarat. Jadi jaksalah yang memang mempunyai kewenangan serta tugas untuk melakukan suatu eksekusi dari putusan pengadilan yang telah mempunyai kekuatan hukum dalm tindak pidana termasuk tindak pidana pembunuhan. Kemudian, mekanisme pelaksanaan putusan pengadilan tindak pidana pembunuhan selesainya proses dari persidangan hakim lalu mengambil suatu keputusan yang diucapkan pada terakhir proses persidangan yang dibuka dan terbuka untuk umum. Putusan dari hakim itu apabila sudah berkekuatan hukum tetap dan tidak diajukan lagi upaya hukum dari terdakwa maka jaksa sebagai eksekutornya yang mempunyai kewenangan untuk menjalankan putusan hakim setelah menerima salinan putusan dari panitera bukan hanya petikan putusan saja sesuai dengan pasal 270 Kitab Undang-undang Hukum Acara Pidana. Putusan hakim itu dijalankan oeh jaksa sesuai pidana apa yang dimuat di dalam putusannya.

\section{Saran}

Adapun saran yang hendka disampaikan, yakni Jaksa sebagai aparat penegak hukum dalam mejalankan tugasnya harus berdasarkan pada aturan-aturan hukum yang berlaku. Jangan sampai jaksa melanggar aturan yang bukan menjadi kewenangannya. Banyaknya kasus yang ditangani oleh kejaksaan sebagai institusi penegak hukum di Negara hukum ini harus benar-benar terwujud hukum yang berkeadilan, berkepastian dan berkemanfaatan. Kemudian, aparat penegak hukum yang melakukan eksekusi haruslah menjalankan dengan secepatnya eksekusi tersebut dan tidak ada pelaku tindak pidana yang terlambat di eksekusi, apalagi jika pelaku melakukan perbuatan tindak pidana pembunuhan yang semestinya dijerat sesuai dengan aturan yang berlaku. Tidak ada lagi kita temui terpidana yang lambat di eksekusi sesaui mekanismenya karena alasan apapun, termasuk karena alasan administratif.

\section{DAFTAR PUSTAKA}

Bahasa, T. penyusun K. P. P. dan P. (1990). Kamus Besar Bahasa Indonesia. Balai Pustaka. 
Effendy, M. (2007). Kejaksaan Republik Indonesia, Posisi dan Fungsinya dari Perspektif Hukum. Ghalia Indonesia.

Gosita, A. (1983). Hukum dan Hak-Hak Anak. Rajawali Pers.

Hamang, M. N. (2003). Beberapa Upaya Hukum bagi Hakim dalam Sidang Pengadilan dalam Rangka Putusan dan Penetapan Hukum yang Adil Menurut Syariat Islam (Perspektif Hadis Nabi SAW). Jurnal Al-Syir'ah, l(2).

Muhammad, R. (2007). Hukum Acara Pidana Kontenporer. Citra Aditya Bakti.

Sutarto, S. (2008). Hukum Acara Pidana (Jilid II). Badan Penerbit UNDIP. 